\title{
Improvement in Properties of Mn-Zn Ferrite Nanoparticles by Rare Earth Doping
}

\author{
Anjali Shrivastava*, A.K. Shrivastava \\ School of Studies in Physics, Jiwaji University, Gwalior, India
}

(Received 11 January 2021; revised manuscript received 24 March 2021; published online 09 April 2021)

\begin{abstract}
Undoped $\mathrm{Mn}_{0.5} \mathrm{Zn}_{0.5} \mathrm{Fe}_{2} \mathrm{O}_{4}$ ferrite nanoparticles and Rare Earth Gadolinium doped $\mathrm{Mn}$-Zn ferrite powder were synthesized and characterized using X-ray Diffractometer (XRD), Fourier transform infrared (FTIR), Transmission Electron Microscopy (TEM) and vibrating sample magnetometer (VSM).A small amount of rare earth oxide can significantly improve the microstructure and magnetic properties. A very fine particle size can be obtained by doping. For all rare earth oxides, a small amount of doping can significantly. The present studies indicate that rare earth doping can be one of the effective ways to improve the performance of soft ferrites.
\end{abstract}

Keywords: Ferrites, Doping, Rare earth, XRD, VSM.

DOI: 10.21272/jnep.13(2).02002

PACS numbers: 75.50.Gg, 87.64.Bx

\section{INTRODUCTION}

Many important signal and sensor/actuator applications require magnetic materials that have low hysteresis in the plot of the magnetic flux density of the material as a function of magnetic field intensity $(B-H$ curve). Materials having this property are referred to as soft magnetic materials. A good soft magnetic material should have a large saturation magnetization to obtain a wide range of operation, and a high permeability to achieve a high magnetization even under a low applied field. It should also have a low coercivity and remanence [1].

$\mathrm{Mn}-\mathrm{Zn}$ ferrites are commercially important materials due to their high permeability and low core losses [2]. The phase purity and the crystalline nature of the ferrites determine their magnetic properties. The magnetic ferrites are also utilized for magneto-rheology [3-5] and microwave absorption [6]. There are many methods available for the synthesis of the different ferrites [717]. The ferrites are usually produced by the ceramic method but the particles obtained by this method are rather large and non-uniform in size. Besides, nonreproducible products in terms of magnetic properties are obtained. In order to overcome the limitations of the ceramic process and to improve the magnetic properties of the Mn-Zn ferrite, the co-precipitation method [18] have been considered an interesting alternative to produce chemically homogeneous powders with fine particle size and good reproducibility. Hirota and co-workers [19] observed that the magnetic and electric properties of the $\mathrm{Mn}-\mathrm{Zn}$ ferrites obtained by co-precipitation are better than that produce by the ceramic process, due to the small particle size of the co-precipitated powders. According to Jeyadevan and co-workers [20], the differences observed in the magnetic properties of the samples prepared by co-precipitation are due to the random distribution of the $\mathrm{Zn}, \mathrm{Mn}$ and Fe ions in the octahedral and tetrahedral sites of the spinel structure, as observed by EXAFS results Many aspects of the production steps of $\mathrm{Mn}-\mathrm{Zn}$ ferrites by co-precipitation can interfere on the final microstructure and magnetic properties such as the stoichiometry ( $\mathrm{Mn}, \mathrm{Zn}$ and $\mathrm{Fe}$ contents), reagent addition order, precipitation $\mathrm{pH}$ and calcination conditions [18, 21-23].

In this paper simple and cost-effective method of synthesis i.e., co-precipitation method has been chosen to obtain uniform and very fine pure and Gadolinium doped Mn-Zn nanoparticles and then characterized.

\section{METHOD OF PREPARATION}

Nanocrystalline Gd doped Mn-Zn ferrites were prepared by co-precipitation method. In perfect stoichiometric proportions manganese chloride, iron (III) chloride and zinc nitrate were taken from their molar solutions. Sodium hydroxide solution was added in the solution with constant stirring. $\mathrm{pH}$ of the samples was maintained at 8 . Reaction time was $90 \mathrm{~min}$ at $75^{\circ} \mathrm{C}$ and precipitates were allowed to settle down at room temperature. The precipitated particles were washed several times with double distilled water to remove the impurities and dried at room temperature. The dried powder was then crushed and calcined at $400{ }^{\circ} \mathrm{C}$ for $2 \mathrm{~h}$.

The synthesized samples were characterized for structural properties using X-ray diffraction technique (XRD Rigaku Miniflex 600). TEM studies including electron diffraction were performed on a JEOL JEM $1230120 \mathrm{KV}$ transmission electron microscope. The magnetic properties of the as-prepared samples were studied using VSM (Lake Shore Cryotronics 7400-S).

\section{RESULTS}

\subsection{X-ray Diffractometer}

X-ray diffraction has been performed for the structural characteristics namely crystallite size, lattice parameter, crystallite phase, lattice strain and X-ray density of as prepared nanoparticle powder samples. The lattice parameters were calculated using the interplanar distance ' $d$ ' values and the respective $(h k l)$ parameters. X- ray diffraction patterns of undoped and

* success.anjali208@gmail.com

The results were presented at the International Conference on Multifunctional Nanomaterials (ICMN2020) 
Gadolinium doped Mn-Zn ferrites with their tentative indexing are shown in Fig. 1. These pattern exhibits all the major peaks related to spinel structure without any impurity. XRD spectrum indicates that (311) is a prominent peak.
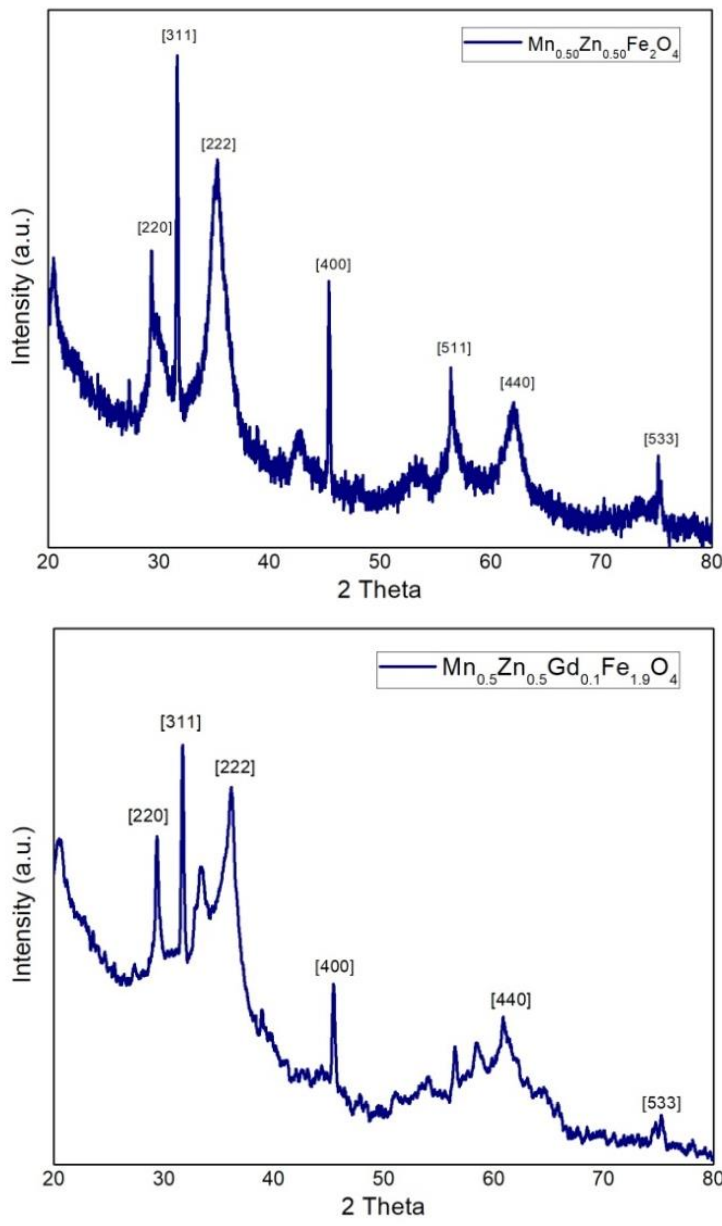

Fig. 1 - XRD pattern of pure and doped Mn-Zn ferrite powder
From the full width at half maxima (FWHM) of peaks, the mean size of the crystals was estimated by using Scherrer's equation given below:

$$
D_{X R D}=\frac{k \lambda}{\beta \cos \theta},
$$

where $D_{X R D}$ is the mean dimension of the crystallites, $k$ is Scherrer's constant taken to be $0.9, \lambda$ is the X-ray wavelength $(\lambda=1.5406 \AA), \beta$ is the broadening of the peak width of half maximum, and $\theta$ is the Bragg's diffraction angle.

The lattice parameter of as-prepared samples was calculated by considering cubic crystal structure, from the plane (311) main peak of spinel structure using the Bragg's equation:

$$
a=d_{h k l} \sqrt{h^{2}+k^{2}+l^{2}},
$$

where $d_{h k l}$ is the interplanar distance, " $a$ " is lattice parameter, and ' $h$ ', ' $k$ ', ' $l$ ' are epy plane indices. The X-ray density $\rho_{x}$ is determined using the equation [24]

$$
\rho_{x}=\frac{Z M}{N_{A} V},
$$

where $Z=8$ (the number of atoms in cubic structure), $N_{A}$ is Avogadro number, $M$ is molecular weight and $V$ is volume of the cubic unit cell: $a^{3}$.

The average crystallite size, lattice parameter, strain, X-ray density and interplanar spacing have been calculated using XRD data are given in Table 1 .

From the XRD data table it is clear that the crystallite size is decreasing with the doping of gadolinium. The lattice parameter is also decreased with doping of gadolinium; it might be due to the difference between the ionic radii of host and doping element. The X-ray density is increased with the doping of gadolinium, it indicates that with the doping of $\mathrm{Gd}$, the electron density of the sample increased.

Table 1 - Values of crystallite size $(D)$, lattice parameter $(a)$, X-ray density $(\rho)$, lattice strain $(\varepsilon)$ and interplanar spacing $(d)$ for $\mathrm{Mn}_{0.5} \mathrm{Zn}_{0.5} \mathrm{Gd}_{x} \mathrm{Fe}_{2-x} \mathrm{O}_{4}$

\begin{tabular}{|l|c|c|c|c|c|}
\hline \multicolumn{1}{|c|}{ Composition } & $D, \mathrm{~nm}$ & $a, \AA$ & $\rho, \mathrm{gm} / \mathrm{cm}^{3}$ & $\varepsilon$ & $d, \AA$ \\
\hline $\mathrm{Mn}_{0.5} \mathrm{Zn}_{0.5} \mathrm{Fe}_{2} \mathrm{O}_{4}$ & 6.60 & 2.8264 & 9.3741 & 4.7735 & 1.6635 \\
\hline $\mathrm{Mn}_{0.5} \mathrm{Zn}_{0.5} \mathrm{Gd}_{0.1} \mathrm{Fe}_{1.9} \mathrm{O}_{4}$ & 5.85 & 9.3654 & 7.3307 & 1.5044 & 2.8238 \\
\hline
\end{tabular}

\subsection{Transmission Electron Microscopy Images}

Transmission electron microscopy has been used to obtain the morphological details of the developed Gadolinium doped $\mathrm{Mn}-\mathrm{Zn}$ ferrite samples. The TEM images of the $\mathrm{Mn}_{0.5} \mathrm{Zn}_{0.5} \mathrm{Fe}_{2} \mathrm{O}_{4}$ and $\mathrm{Mn}_{0.5} \mathrm{Zn}_{0.5} \mathrm{Gd}_{0.1} \mathrm{Fe}_{1.9} \mathrm{O}_{4}$ samples are depicted at different magnifications in Fig. 2. It is seen that most of the particles are fine and spherical and when gadolinium doping occur the particles gets much finer.

\subsection{Hysteresis Measurements}

Magnetic measurements were carried out of the asprepared samples using vibrating sample magnetome- ter (VSM). From these measurements, the saturation magnetization $\left(M_{S}\right)$, remanent magnetization $\left(M_{r}\right)$ and coercivity $\left(H_{C}\right)$ were evaluated. Fig. 3 shows the magnetic characteristics of $\mathrm{Mn}_{0.5} \mathrm{Zn}_{0.5} \mathrm{Gd}_{x} \mathrm{Fe}_{2}{ }_{-} \mathrm{O}_{4}$ nanoferrites. The magnetic moment $\left(n_{B}\right)$ has been calculated using the relation $n_{B}=\left(M \cdot M_{S}\right) / 5585$, where $M$ is the molecular weight of $\mathrm{Mn}_{0.5} \mathrm{Zn}_{0.5} \mathrm{Gd}_{x} \mathrm{Fe}_{2}{ }_{-x} \mathrm{O}_{4}$ ferrites and $M_{S}$ is the saturation magnetization of the samples. The values of the saturation magnetization $\left(M_{S}\right)$, coercivity $\left(H_{C}\right)$, remanence $\left(M_{r}\right)$, and magnetic moment $\left(n_{B}\right)$ have been calculated and are given in Table 2. From Fig. 3, it is clear that the saturation magnetization increases with the doping of Gadolinium. 

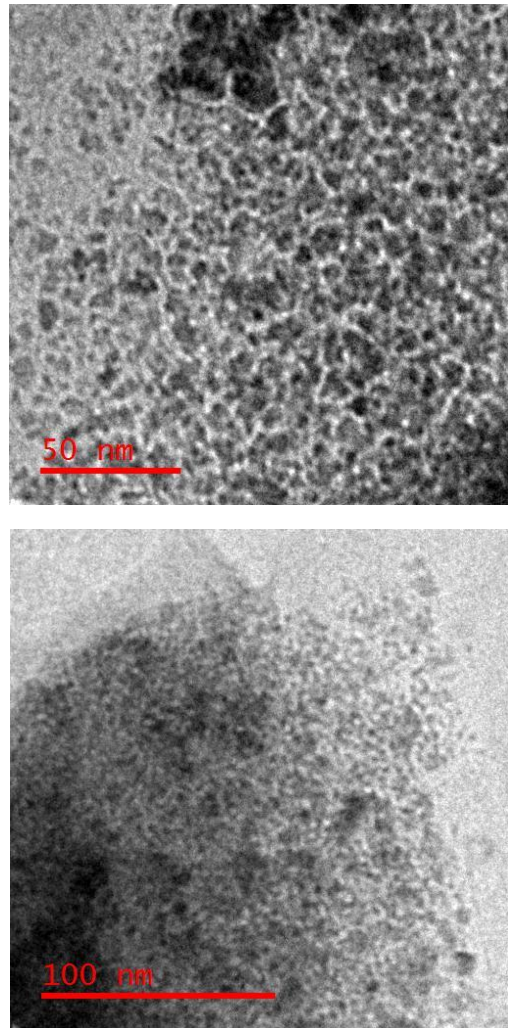

Fig. 2 - TEM images of (a) $\mathrm{Mn}_{0.5} \mathrm{Zn}_{0.5} \mathrm{Fe}_{2} \mathrm{O}_{4}$ and (b) (b) $\mathrm{Mn}_{0.5} \mathrm{Zn}_{0.5} \mathrm{Gd}_{0.1} \mathrm{Fe}_{1.9} \mathrm{O}_{4}$

\section{CONCLUSIONS}

Undoped and gadolinium doped Mn-Zn nanoparticles have been synthesized using co-precipitation method. The

\section{REFERENCES}

1. J.Y. Park, M.G. Allen, J. Micromech. Microeng. 8, 307 (1998).

2. C. Rath, K.K. Sahu, S. Anand, S.K. Date, N.C. Mishra, R.P. Das, J. Magn. Magn. Mater. 202, 77 (1999).

3. A.V. Anupama, V.B. Khopkar, V. Kumaran, B. Sahoo, Phys. Chem. Chem. Phys. 20, 20247 (2018).

4. A.V. Anupama, V. Kumaran, B. Sahoo, Adv. Powder Technol. 29, 2188 (2018).

5. A.V. Anupama, V. Kumaran, B. Sahoo, Rheol. Acta 58, 273 (2019).

6. H.K. Choudhary, S.P. Pawar, R. Kumar, A.V. Anupama, S. Bose, B. Sahoo, Chemistry Select 2, 830 (2017).

7. A.S. Vanetsev, V.K. Ivanov, A. Yu, D. Tretyakov, Chemistry (Easton). 387, 640 (2002).

8. V.D. Sudheesh, N. Thomas, N. Roona, H. 2Choudhary, B. Sahoo, N. Lakshmi, V. Sebastian, J. Alloys Compd. 742, 577 (2018).

9. V. Kashyap, S.K. Sing, S.Kurungot, Chemistry Select 2, 7845 (2017).

10. A. Manikandan, J.J. Vijaya, L.J. Kennedy, M. Bououdina, Ceram. Int. 39, 5909 (2013).

11. N. Millot, S. Le Gallet, D. Aymes, F. Bernard, Y. Grin, J. Eur. Ceram. Soc. 27, 921 (2007).

12. V. Rathod, A.V. Anupama, V.M. Jali, V.A. Hiremath, B. Sahoo, Ceram. Int. 43, 14431 (2017)

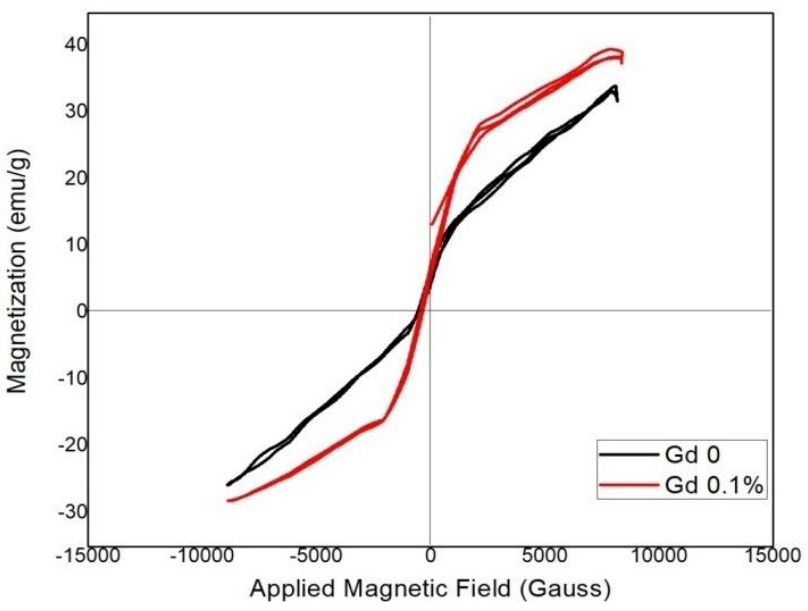

Fig. $3-M$ - $H$ curve for as prepared samples

Table 2 - Magnetic measurement of $\mathrm{Mn}_{0.5} \mathrm{Zn}_{0.5} \mathrm{Fe}_{2} \mathrm{O}_{4}$ and $\mathrm{Mn}_{0.5} \mathrm{Zn}_{0.5} \mathrm{Gd}_{0.1} \mathrm{Fe}_{1.9} \mathrm{O}_{4}$ samples

\begin{tabular}{|l|c|c|c|c|}
\hline Composition & $\begin{array}{c}M_{s}, \\
\text { emu/g }\end{array}$ & $\begin{array}{c}H_{c}, \\
\text { Gauss }\end{array}$ & $\begin{array}{c}M_{r}, \\
\text { emu/gm }\end{array}$ & $\begin{array}{c}n_{B}, \\
\text { erg-gm }\end{array}$ \\
\hline $\mathrm{Mn}_{0.5} \mathrm{Zn}_{0.5} \mathrm{Fe}_{2} \mathrm{O}_{4}$ & 34.16 & 503.17 & 6.87 & 1.441 \\
\hline $\mathrm{Mn}_{0.5} \mathrm{Zn}_{0.5} \mathrm{Gd}_{0.1} \mathrm{Fe}_{1.9} \mathrm{O}_{4}$ & 39.57 & 426.79 & 7.22 & 1.650 \\
\hline
\end{tabular}

as-prepared nanomagnetic particles were characterized for their structural, morphological and magnetic properties. In comparison to undoped ferrite nanoparticles, the crystallite size decreases with gadolinium doping. The surface morphology of these fine particles shows the presence of ultra-fine particles when doped with gadolinium. The saturation magnetization increases while we dope the material with gadolinium.

13. S. Komarneni, M.C. D'Arrigo, C. Leonelli, G.C. Pellacani, H. Katsuki, J. Am. Ceram. Soc. 81, 3041 (2005).

14. J. Liu, H. He, X. Jin, Z. Hao, Z. Hu, Mater. Res. Bull. 36, 2357 (2001).

15. R. Dom, R. Subasri, K. Radha, P.H. Borse, Solid State Commun. 151, 470 (2011).

16. L. Kumar, P. Kumar, V. Kuncser, S. Greculeasa, B. Sahoo, M. Kar, Mater. Chem. Phys. 211, 54 (2018).

17. S.V. Bhandare, R. Kumar, A.V. Anupama, H.K. Choudhary, V.M. Jali, B. Sahoo, Ceramics Int. 46, 17400 (2020).

18. S.R. Janasi, F.J.G. Landgraf, M. Emura, D. Rodrigues, J. Magn. Magn. Mater. 238, 168 (2002).

19. K. Hirota, T. Aoyama, S. Enomoto, M. Yoshinaka, O. Yamaguchi, J. Magn. Magn. Mater. 205, 283 (1999).

20. B. Jeyadevan, K. Tohji, K. Nakatsuka and A. Narayanasamy, J. Magn. Magn. Mater. 217, 99 (2000).

21. H. Robbins, Proceedings of the International Conference on Ferrites, 7 (Japan: 1970).

22. S.R. Janasi, D. Rodrigues, F.J.G. Landgraf and M. Emura, IEEE Trans. Magn. 36, 3327 (2000).

23. S.R. Janasi, D. Rodrigues, F.J.G. Landgraf, Mater. Sci. Forum 498-499, 119 (2005).

24. B.D. Cullity, Elements of X-rays Diffraction, 338 (2nd ed.) (Addison Wesley: Publishing Co.: Philippines: 1978). 


\title{
Поліпшення властивостей наночастинок фериту Mn-Zn методом легування рідкоземельними елементами
}

Anjali Shrivastava, A.K. Shrivastava

School of Studies in Physics, Jiwaji University, Gwalior, India

\begin{abstract}
Нелеговані наночастинки фериту $\mathrm{Mn}_{0.5} \mathrm{Zn}_{0.5} \mathrm{Fe}_{2} \mathrm{O}_{4}$ та феритовий порошок $\mathrm{Mn}-\mathrm{Zn}$, легований рідкоземельним гадолініем, були синтезовані та охарактеризовані за допомогою рентгенівського дифрактометра (XRD), інфрачервоної спектроскопії з перетворенням Фур'є (FTIR), просвічуючої електронної мікроскопії (TEM) та магнітометра з вібруючим зразком (VSM). Невелика кількість рідкоземельного оксиду може значно покращити мікроструктуру та магнітні властивості. Дуже дрібний розмір частинок можна отримати за допомогою легування. Для всіх рідкісноземельних оксидів незначна кількість легування може бути суттевою. Дані дослідження вказують на те, що рідкісноземельне легування може бути одним із ефективних способів поліпшити характеристики м'яких феритів.
\end{abstract}

Ключові слова: Ферити, Легування, Рідкоземельний, XRD, VSM. 